\title{
Assessment of the Consumers' Awareness and Marketing Prospects of Organic Fruits and Vegetables in Techiman, Ghana
}

\author{
Ayisaa Adams ${ }^{1}$, Jacob K. Agbenorhevi ${ }^{1, *}$, Francis Alemawor ${ }^{1}$, Herman E. Lutterodt ${ }^{1}$, Gilbert O. Sampson ${ }^{2}$ \\ ${ }^{1}$ Department of Food Science and Technology, Kwame Nkrumah university of Science and Technology, Kumasi, Ghana \\ ${ }^{2}$ Department of Hospitality and Tourism, University of Education, Winneba, College of Technology Education, Kumasi, Ghana \\ *Corresponding author: jkagbenorhevi@yahoo.com, jkagbenorhevi.cos@knust.edu.gh
}

\begin{abstract}
The consumers' awareness and willingness to pay premium for organic fruits and vegetables as well as the marketing prospects of these organic foods in the Techiman Market of Ghana were assessed. A face-to-face interview technique was employed using a structured questionnaire for this cross-sectional study. Out of 330 questionnaires administered, 318 were valid and included in the data analysis accordingly. Results showed that most of the consumers (74.53\%) were aware of organic foods and the majority willing to pay up to $50 \%$ premium for the organic fruits and vegetables. The study revealed that key factors such as age, marital status, income and knowledge of chemical residues and their associated health risks significantly influenced consumers' choice and willingness to pay a premium for organic fruits and vegetables. The estimated market potential for the organic fruits and vegetables were GH\$3,514,383,194.70 ( 926 million USD) and GH\$5,341,348,087.50 ( $\sim 1407$ million USD) per year, respectively. Most consumers are aware of organic foods in the Techiman market of Ghana and they became aware generally through the radio and school/books. Most of the consumers acknowledged that they had concerns about the environmental and health risks associated with chemically grown fruits and vegetables on their health and wellbeing. Almost all the consumers were willing to pay up to $50 \%$ premium for the organic fruits and vegetables purchased in the Techiman municipality.
\end{abstract}

Keywords: organic fruits and vegetables, consumer awareness, willingness to pay price premium, Logit regression analysis

Cite This Article: Ayisaa Adams, Jacob K. Agbenorhevi, Francis Alemawor, Herman E. Lutterodt, and Gilbert O. Sampson, "Assessment of the Consumers' Awareness and Marketing Prospects of Organic Fruits and Vegetables in Techiman, Ghana.” Journal of Food Security, vol. 6, no. 2 (2018): 55-66. doi: 10.12691/jfs-6-2-2.

\section{Introduction}

Organic farming is defined as the holistic farming system which promotes and enhances agro ecosystem health, including biodiversity, biological cycles and soil biological activity, and does not involve the use of modern inputs such as synthetic pesticides and chemical fertilizers $[1,2]$. Organic farming and its produce provide various benefits to farmers, consumers and other stakeholders. Organic foods are rapidly emerging as an important food industry in the world with Ghana not being an exception. Consumers benefit from organic foods through consumption of which fruits and vegetables are no exception. The main difference between organic and conventional farming dwell on soil and pest management aspects practices $[3,4,5]$. Thus organic farming does not contribute to water pollution and destruction of aquatic life [4].

With food safety, optimum nutrition and environmental quality issues high on the agenda of most policy makers all over the world, organic food has speedily emerged as an important food industry in the developed countries $[6,7]$ and Ghana is not an exception. For instance, the total retail organic food sales in United States increased from 178 million US dollars in 1980 to 1 billion US dollars in 1990 and reached 7.8 billion US dollars in 2000 [8].

Agriculture is the most important sector of the Ghanaian economy, it employs about two thirds of the population and contributes to half of the country's Gross Domestic Products (GDP) and export earnings [9]. Agricultural production in Ghana comprises of organic and conventional methods. Although the organic sub-sector in Ghana is relatively underdeveloped, land area under organic cultivation has increased from an estimated 5,453 hectares (in 2003) to 19,132 hectares (in 2006) which accounts for only $0.13 \%$ of the total area under agricultural production in Ghana [10]. The most commonly grown organic vegetables in Ghana includes; lettuce, cabbage, green pepper, carrot, tomato, garden eggs, green beans and spring onions, which are often used in exotic diets and frequently eaten raw. Organic fruits also include; pineapple, pawpaw, mango, orange, pear and water melon [1].

Fruit and vegetable production in the urban, peri-urban and rural areas plays important roles in the socio-economic 
development of Ghana. It ensures food security, provides raw materials for local industries, and generates foreign exchange, employment and income for a section of the Ghanaian population [1]. Although organic farming has been identified as an effective way to improve food safety and environmental quality [11], its adoption in most sub-Saharan African countries is highly determined by the consumers' awareness and demand for organic food produce [12]. It is established in literature that marketability and nutritional knowledge are key factors that influence eating habit of consumers. This study therefore sought to assess consumer awareness and marketing prospects of organic fruits and vegetables in Techiman in the Brong Ahafo Region of Ghana.

\section{Methodology}

\subsection{Study Design}

The cross sectional study design was used in this study. The study period was from September to November, 2014. The consents of participants were sought and those who voluntarily accepted to take part in this study were recruited for the study. The face-to-face interview technique was employed using a structured questionnaire. This was to provide the opportunity to explain questions which were difficult to answer, to obtain the exact information needed for the study, and also to afford the interviewer the opportunity to educate the respondents.

\subsection{Study Site}

The study was carried out in the Techiman market. Techiman is located in the Brong Ahafo region of Ghana. Techiman lies on latitude $7^{\circ} 35^{\prime} 10^{\prime}$ ' $\mathrm{N}$ and longitude $1^{\circ}$ 56' 28' ' W, and serves as the capital of the Techiman Municipality (Figure 1) with a population of about 67,241 [13]. Techiman together with Sunyani are the two major cities of the Brong Ahafo region. Farming and trading are the major occupation for the indigenous people of Techiman.

\subsection{Study Population and Sampling}

All consumers in the Techiman Market, between the ages of 18 and 60 years, were considered and included in the study. A convenient sampling technique was used to select three hundred and thirty (330) respondents for the stud.

\subsection{Instrument for Data Collection}

The face-to-face interview technique was employed using a structured questionnaire. This was to provide the opportunity to explain questions which were difficult to answer respondents, to obtain the exact information needed for the study, and also to afford the interviewer the opportunity to educate the respondents when necessary. The questionnaire comprised of five sections viz., demography, purchase of organic foods, market potential for organic foods, attitudes and perception towards organic foods and lastly consumers' willingness to pay for organic foods.

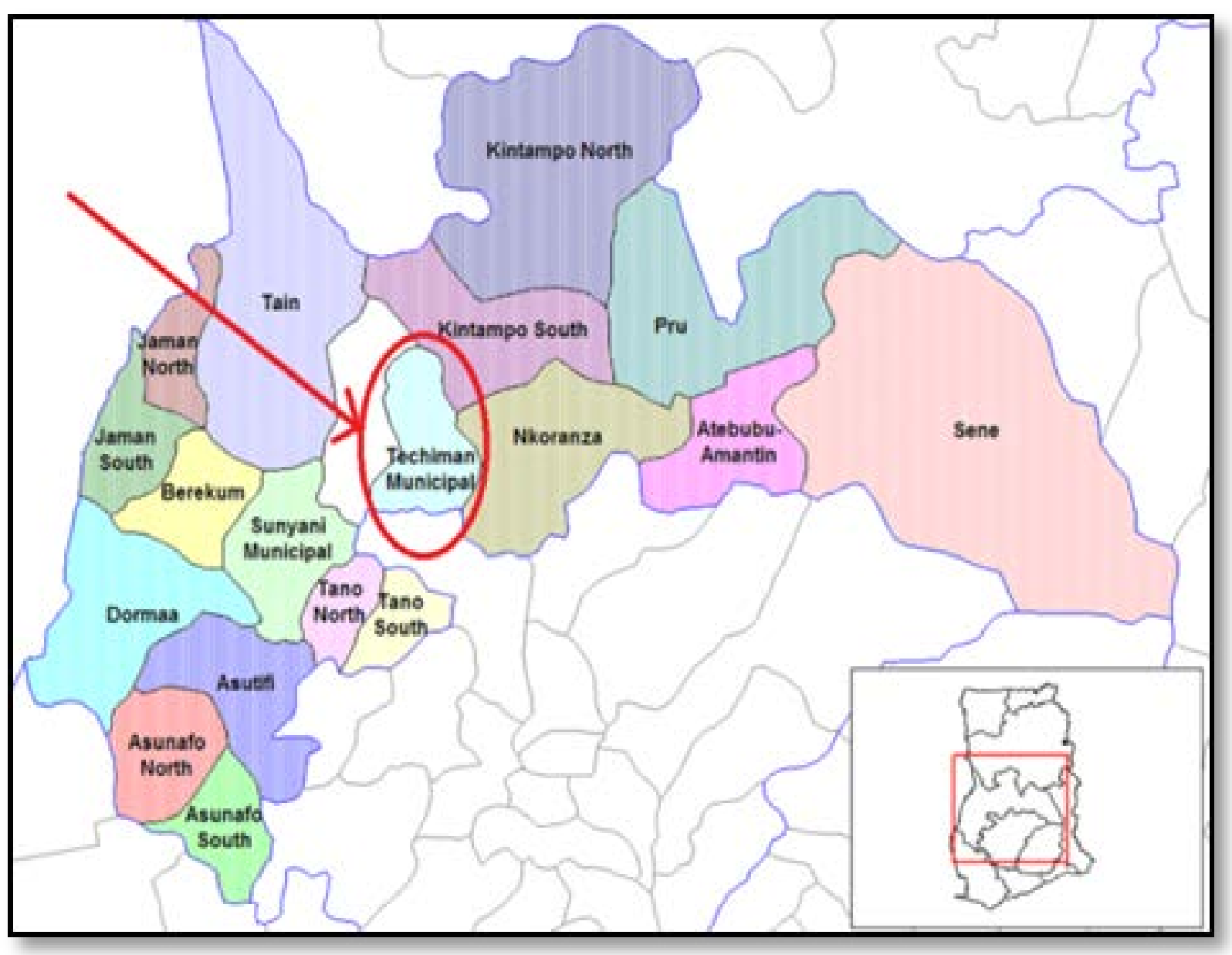

Figure 1. Regional Map of Brong Ahafo 


\subsection{Data Analysis}

The data obtained was analysed using the Statistical Package for Social Scientist (SPSS) software (version 16.0 of SPSS Inc., Chicago, IL, USA). Descriptive analysis of variables was conducted using frequency analysis and mean tests while the willingness of consumers to pay for organic fruits and vegetables with regards socio-demographic characteristics and awareness variables were analysed using the logit regression analysis.

\section{Results and Discussions}

\subsection{Socio-Demographic Characteristics}

The socio-demographic characteristics of the respondents recruited for this study are shown in Table 1 . Most of the respondents were females (68.87\%) with males accounting for the remaining $31.13 \%$. The high percentage of females may be attributed to the fact that most women are responsible for the purchasing of groceries and preparing of food [14], and are involved in marketing activities in Ghana. With regards to educational levels of the respondents, $58.49 \%$ had basic education, $9.43 \%$ had secondary education and $20.76 \%$ had tertiary education. However, about $11.32 \%$ of them had no formal education suggesting that this study captured more educated consumers. The average household size of the respondents was 4 persons per household, and this is in agreement with the national average household size of 4 persons per household in the 2010 population and housing census [13].

Table 1. Socio-Demographic Characteristics of Consumers

\begin{tabular}{|c|c|c|c|}
\hline \multicolumn{2}{|l|}{ Variable } & \multirow{2}{*}{$\begin{array}{c}\text { Frequency } \\
99\end{array}$} & \multirow{2}{*}{$\begin{array}{c}\text { Percentage (\%) } \\
31.13\end{array}$} \\
\hline Condon & Male & & \\
\hline Gender & Female & 219 & 68.87 \\
\hline \multirow{3}{*}{ Age } & Below 30 years & 114 & 35.85 \\
\hline & 30 - 50 years & 174 & 54.72 \\
\hline & Above 50 years & 30 & 9.43 \\
\hline \multirow{4}{*}{$\begin{array}{l}\text { Educational } \\
\text { Level }\end{array}$} & No Education & 36 & 11.32 \\
\hline & Basic Education & 186 & 58.49 \\
\hline & Secondary Education & 30 & 9.43 \\
\hline & Tertiary Education & 66 & 20.76 \\
\hline \multirow{4}{*}{$\begin{array}{l}\text { Marital } \\
\text { Status }\end{array}$} & Single & 87 & 27.36 \\
\hline & Married & 216 & 67.93 \\
\hline & Divorced & 12 & 3.77 \\
\hline & Widow & 3 & 0.94 \\
\hline \multirow{4}{*}{ Occupation } & Formally Employed & 78 & 24.53 \\
\hline & Self Employed & 177 & 55.66 \\
\hline & Unemployed & 21 & 6.60 \\
\hline & Students & 42 & 13.21 \\
\hline \multicolumn{2}{|l|}{ Variable } & Mean & $\begin{array}{l}\text { Standard } \\
\text { Deviation }\end{array}$ \\
\hline \multicolumn{2}{|c|}{ Average Years of Education } & 9.00 & 4.37 \\
\hline \multicolumn{2}{|c|}{ Household Size } & 4.26 & 2.27 \\
\hline \multicolumn{2}{|c|}{ Household Income/Month (GHG) } & 814.90 & 571.50 \\
\hline
\end{tabular}

The unemployment rate of the respondents in the current study is higher than that the unemployment rate recorded in the Ghana living standards survey from
September 2005 to September 2006 which was 3.6\% [15]. The average household income per month of the respondents was GH\$814.90, as shown in Table 1. The average household income per month of the respondents was lower than the average annual household income which was GH\$1,217.00 recorded in the Ghana living standards survey [15]. This may be as a result of the informal or peasant farming occupation of the population because they did not have any monthly income recorded. Also more than half of the respondents (54.72\%) were middle aged (30 - 50 years), 35.85\% of the respondents were below 30 years while $9.43 \%$ of them were above 50 years. This means that most of the consumers on the market were 18 to 50 years, as shown in Table 1 . With regards to marital status, most of the respondents (67.93\%) were married, $27.36 \%$ of them were single, $3.77 \%$ were divorced and $0.94 \%$ were widows.

\subsection{Consumers' Knowledge on Organic Foods}

As shown in Table 2, 74.53\% of the respondents indicated that they were aware of organic foods while $25.47 \%$ of them were unaware of organic foods. More than one third of those who knew about organic foods obtained the knowledge through multimedia; radio (36.71\%), newspaper (5.06\%), television (16.46\%), books (22.78\%) with less than $20 \%$ obtaining the knowledge through friend and relations. The high percentage of awareness through the radio could be attributed to the increasing number of radio stations in Ghana and inclusion of health segments with emphasis of healthy living. Literature suggest that adequate knowledge on organic products (food and/ or medicine) can affect attitudes and perceptions about the product and, ultimately, buying decisions[16-23]. Consumer education and awareness creation on organic foods must be intensified because there is still a segment of the consumers who are not yet informed about organic foods (25.47\%) from this study.

\subsection{Consumers' Behaviour towards Organic Foods}

Based on the market preference, $54.01 \%$ of the respondents indicated that they would like to purchase organic products from the farm gate, 36.29\% from the market retailers and $9.70 \%$ from the supermarkets. The proportion of respondents who would like to purchase organic products from the supermarkets is inconsistent with a previous study [24] which observed $80.9 \%$ of consumers making their purchases from the supermarkets. None of the respondents indicated that they would like to purchase organic products from street hawkers, as shown in Table 3. These results indicate that most consumers would like to purchase their food stuffs from farmers or in the open market. From the results obtained on the mode of differentiation, $40.08 \%$ of the respondents stated that they want organic products to be differentiated from conventional products by labelling, about $49.79 \%$ of the consumers indicated they want special markets or shops to be created for organic products in Ghana whereas 10.13\% of the consumers indicated they want organic products to be labelled and sold in special markets or shops. 
The motivation for purchase of organic products was attributed to health concerns by majority of the respondents (73.84\%). This result is similar to a previous study [25] which reported that most Swedish consumers consider organic fruits and vegetables to be healthier as compared to their conventionally produced alternatives. Other studies have also shown that health is a strong reason why consumers buy organic products [26,27]. Other reasons why the respondents would purchase organic fruits and vegetables were based on safety grounds (22.78) and taste (3.38\%). This result agrees with other existing consumer surveys which found taste as one of the reasons why consumers purchase organic fruits and vegetables [25,27]. None of the respondents admitted they purchase organic products based on environmental reasons, as shown in Table 3. This result agrees with a previous study [28] which indicated that organic food consumers were more concerned about pesticide residues and nutritional values, and less so with environmental stewardship. This trend can be attributed to lack of public awareness of environmental as well as ecological preservation among the populace.

Table 2. Consumers' Knowledge on Organic Foods

\begin{tabular}{llcc}
\hline Variable & & Frequency & Percentage \\
\hline Awareness of & Yes & 237 & 74.53 \\
Organic Foods & No & 81 & 25.47 \\
\hline Source of & Radio & 87 & 36.71 \\
Information & News papers & 12 & 5.06 \\
& Television & 39 & 16.46 \\
& Friends/family & 45 & 18.99 \\
& School/Books & 54 & 22.78 \\
\hline
\end{tabular}

Table 3. Consumers’ Purchasing Behaviour

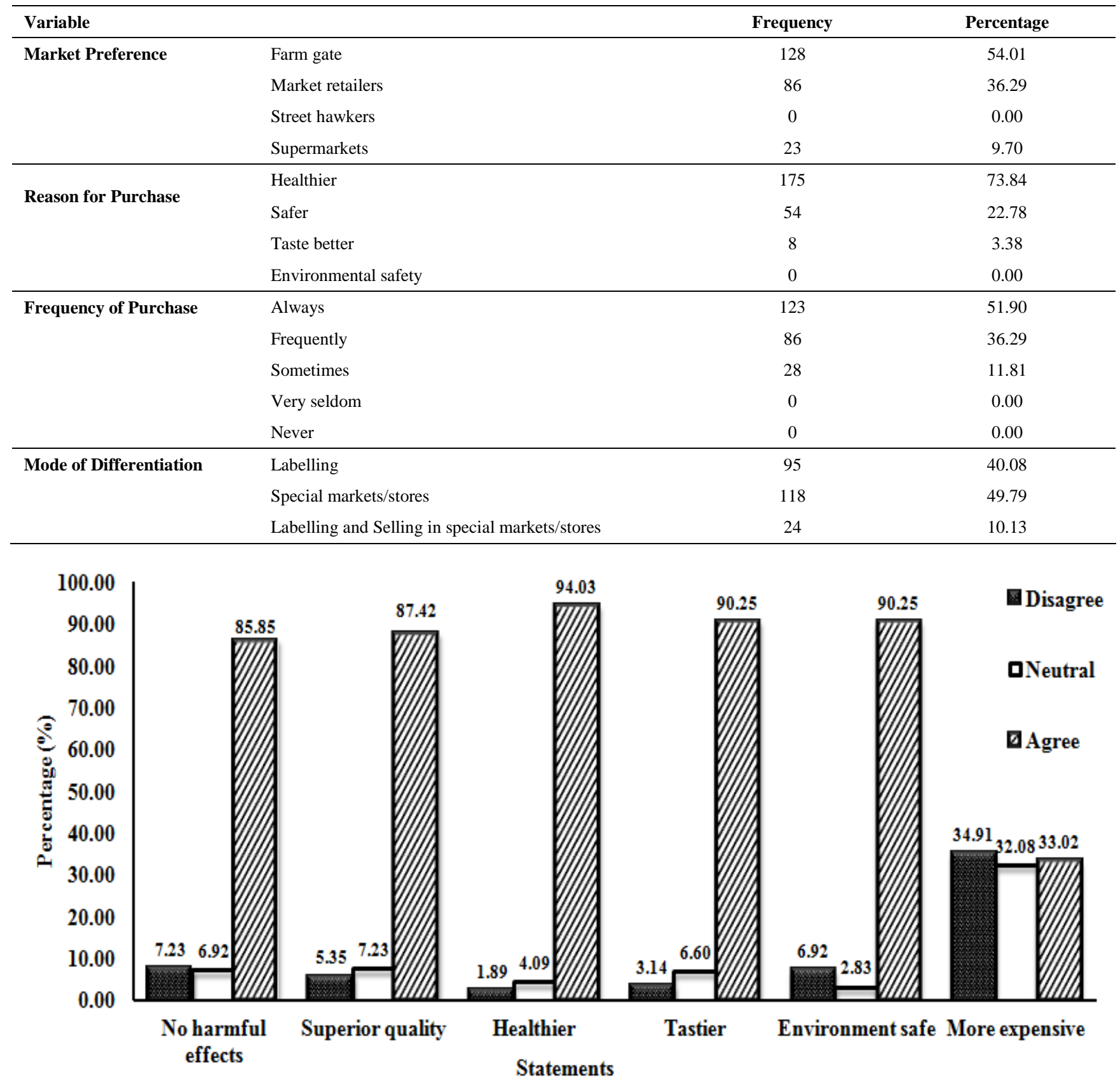

Figure 2. Consumers' Perception on Organic Foods 


\subsection{Consumers' Perception on Organic Fruits and Vegetables}

Consumers' perception on the quality, benefit, environmental risk and cost associated with the consumption of organic fruits and vegetables were investigated. As shown in Figure 2, 85.85\% of the consumers agreed that the consumption of organic fruits and vegetable has no harmful effect. This finding is supported by a previous study [29] which concluded that organic food buyers were more concerned with pesticides residues, additives and preservatives as compared to non-buyers. Also $87.42 \%$ agreed that as compared to conventional products, organic products are of superior quality. This means that most of the respondents indicated that organic fruits and vegetables were of superior quality over their conventional produced fruits and vegetables. Again, some of the respondents (90.25\%) agreed that organic products are tastier as compared to the conventional alternatives. This means that most of the respondents indicated that organic fruits and vegetables were of superior benefit over their conventional produced fruits and vegetables. These benefits notwithstanding, $34.91 \%$ of the respondents agreed that organic fruits and vegetables were more expensive as compared to the conventional fruits and vegetables.

\subsection{Characteristics Consumers Seek When Buying Organic Fruits and Vegetables}

Consumer preference for organic foods is based on a general perception that organic products have more desirable characteristics than conventionally grown alternatives. Apart from health, food safety and environmental considerations, several other product characteristics such as appearance, freshness, taste, nutritive value, and other sensory characteristics influence consumer preferences [30]. In this study, the outstanding characteristics consumers looked for when purchasing organic fruits were freshness (88.68\%) and colour/ripeness (80.57\%) whereas size (64.53\%) and hardness (58.68\%) were the least characteristics as shown in Figure 3. The findings of this study is supported by a previous study [31] which reported that respondents in California rated fresh-tasting and fresh-looking grapes as the most desirable attribute. Another study [32] also concluded that freshness and sensory attributes were the most important considerations in purchasing organic foods.

\subsection{Consumers' Willingness to Pay for Organic Fruits and Vegetables}

The distribution of consumers' willingness to pay (WTP) for the selected organic fruits and vegetables are presented in Figure 5 and Figure 6, respectively. About $88.68 \%$ of the consumers were WTP a premium for water melon, $78.30 \%$ of them for mango, $81.13 \%$ of them for pawpaw, $77.36 \%$ of them for pineapple while $85.85 \%$ of them for orange (Figure 5).

Among the vegetables, $85.85 \%$ of the consumers were WTP a premium for green pepper, $83.96 \%$ of them for carrot, $84.91 \%$ of them for cabbage, $87.74 \%$ of them for tomato whereas $82.02 \%$ of them for garden egg (Figure 6). These findings are in agreement with a previous study [33] which indicated that $82 \%$ of consumers were WTP a premium for organic fruits and vegetables. Similar findings [34] also reported that approximately $89 \%$ WTP for pesticidesfree fresh fruits and vegetables. Also, Nouhoheflin et al., [35] indicated that $86 \%$ of the consumers in Ghana were WTP higher price premium for organic vegetables.

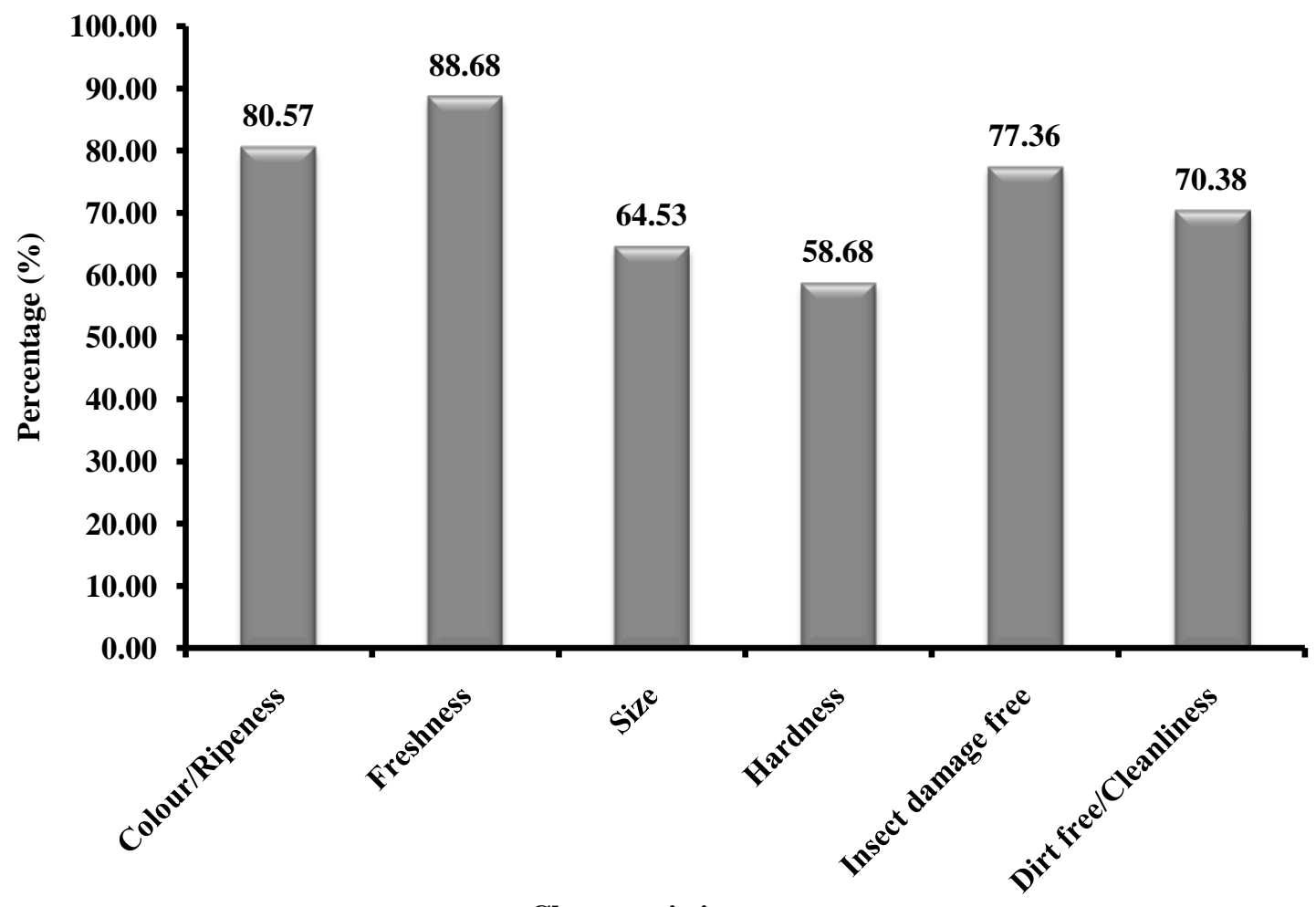

Characteristics

Figure 3. Characteristics consumers would seek when buying organic fruits 


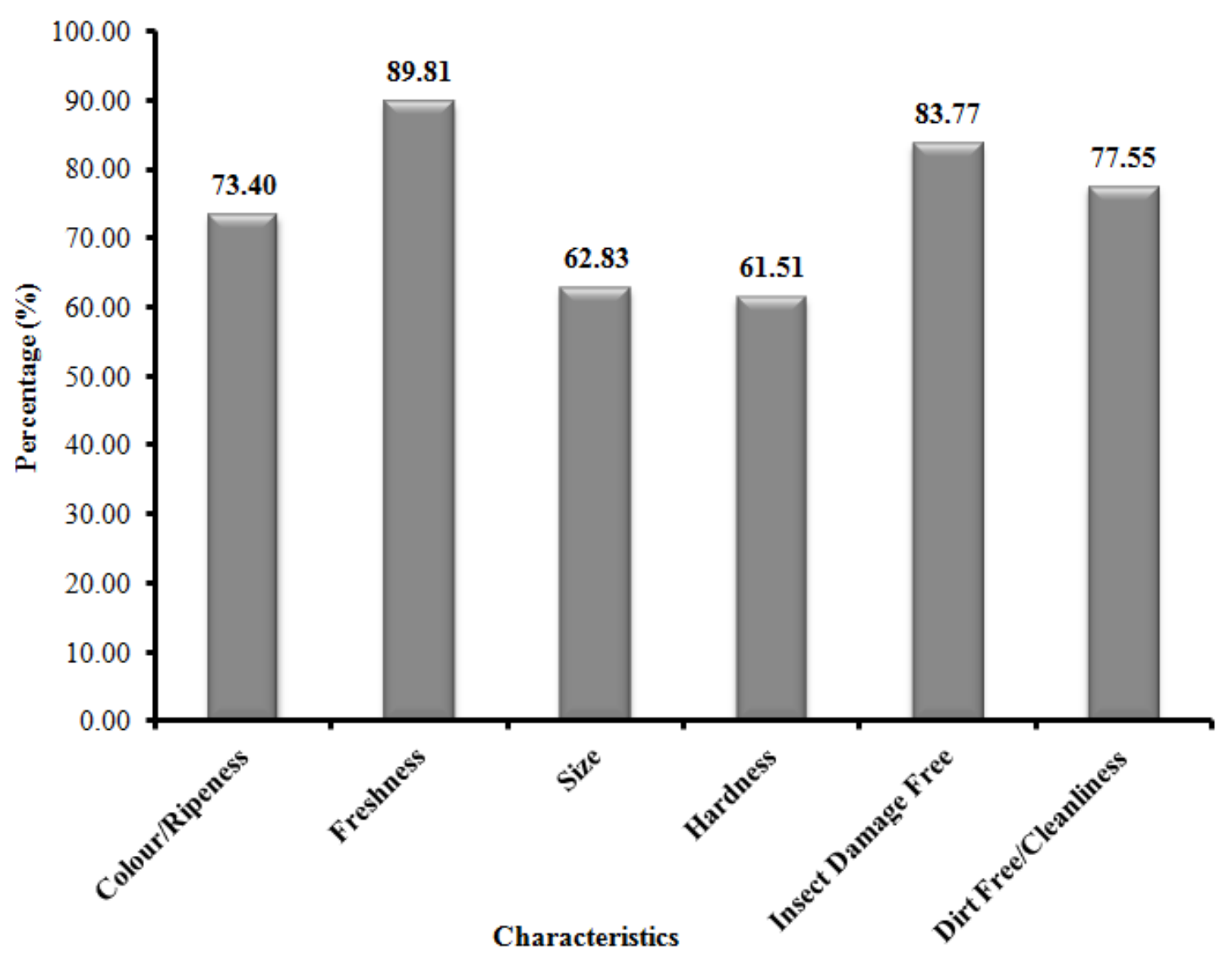

Figure 4. Characteristics consumers would seek when buying organic vegetables

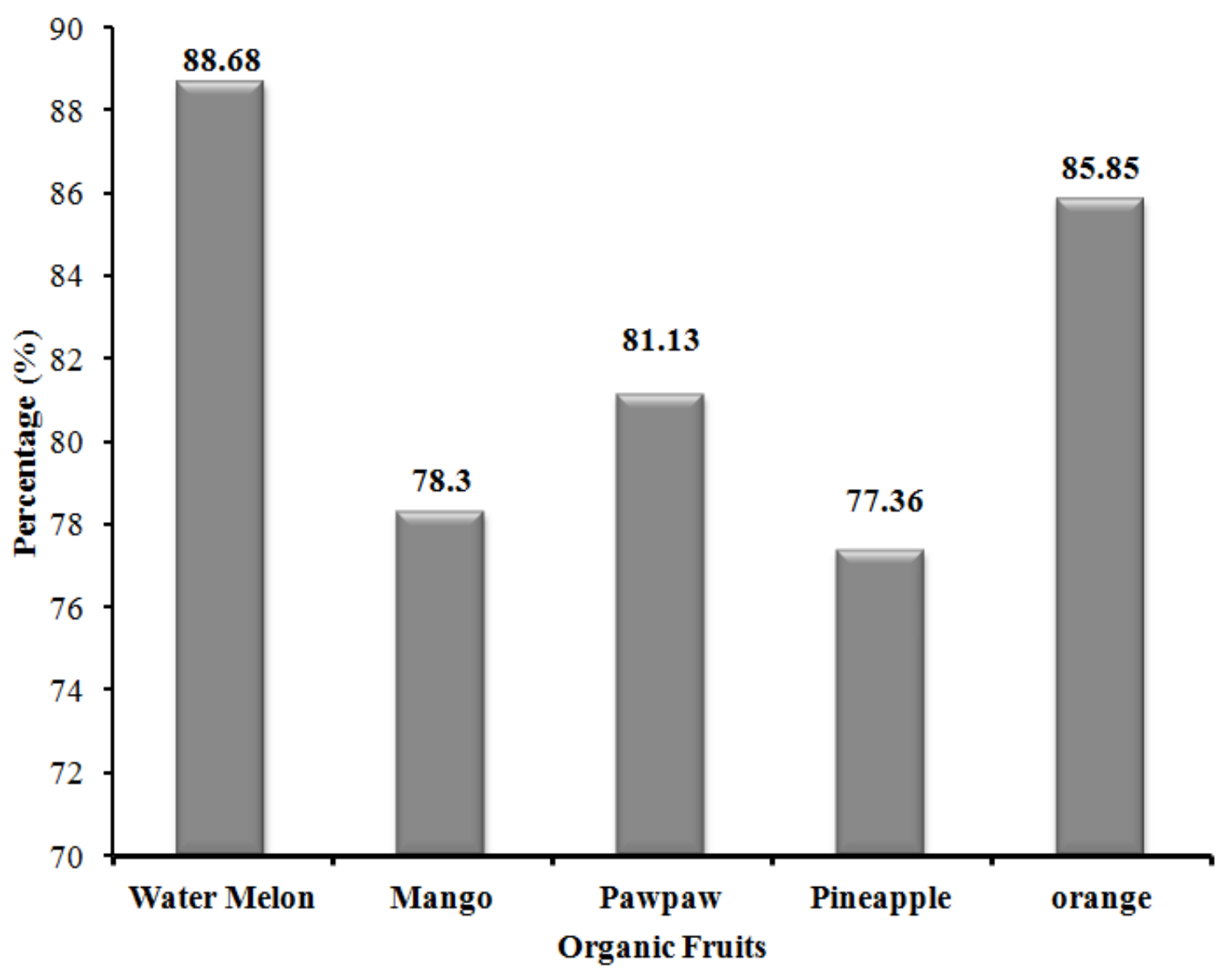

Figure 5. Consumers' willingness to pay a premium for organic fruits 


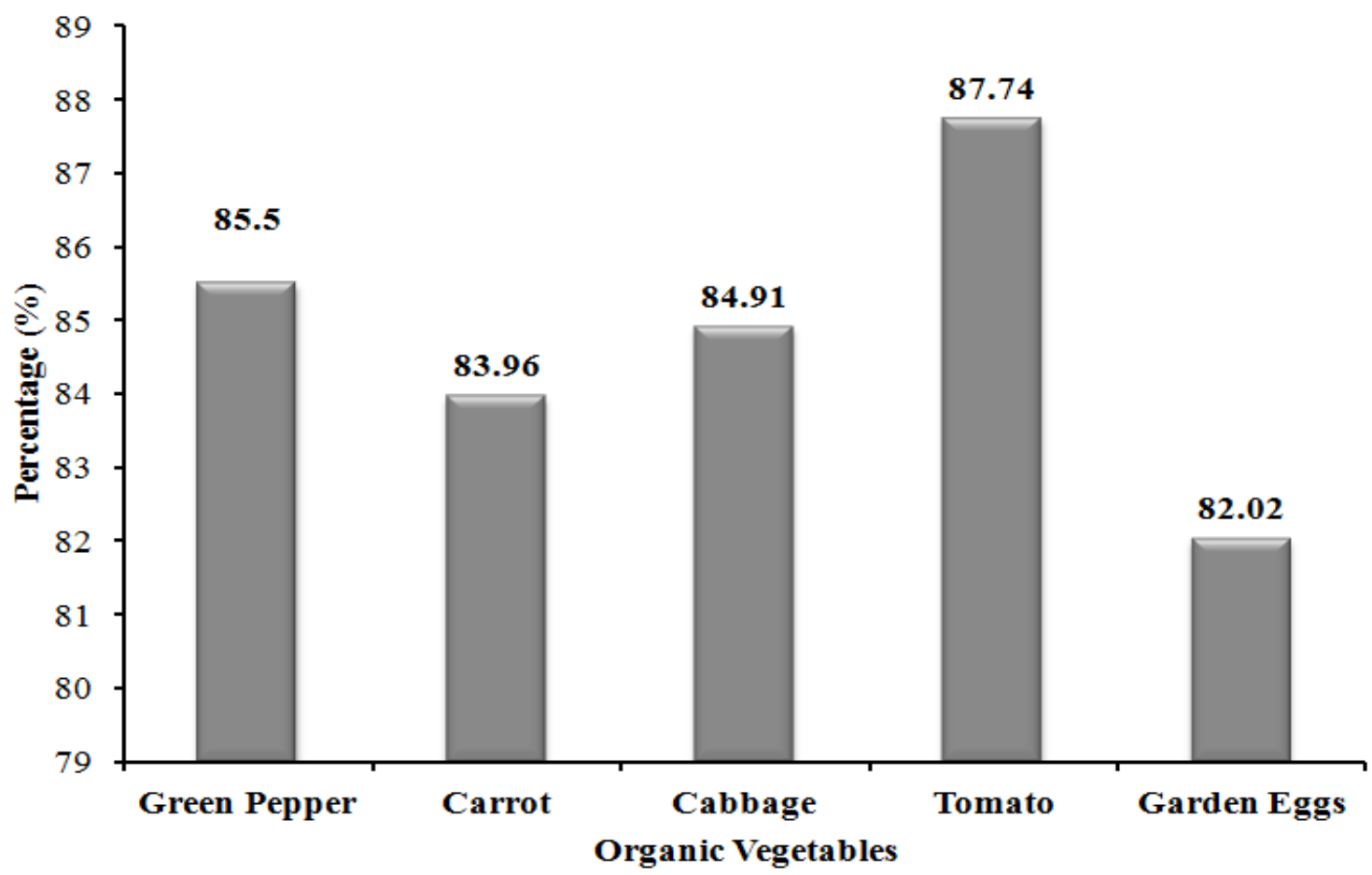

Figure 6. Consumers' willingness to pay a premium for organic vegetables

Table 4. Consumers' Health Concerns on Fruits and Vegetables

\begin{tabular}{llcc}
\hline Variable & & Frequency & Percentage \\
\hline \multirow{2}{*}{ Knowledge of chemical residues in fruits and vegetables } & Yes & 294 & 92.45 \\
& No & 24 & 7.55 \\
\hline Knowledge of diseases associated with the consumption of & Yes & 256 & 87.07 \\
chemically grown fruits and vegetables & No & 38 & 12.93 \\
\hline & Blood pressure & 12 & 4.08 \\
& Heart attack & 26 & 8.84 \\
Diseases associated with the consumption of chemically grown & Cancer & Food poisoning & 28.57 \\
fruits and vegetables & Typhoid & 60 & 20.41 \\
& Diabetes & 19 & 6.64 \\
\hline Knowledge on effects of synthetic chemicals on the & No response & 15 & 5.10 \\
environment & Yes & 78 & 26.53 \\
\hline & No & 280 & 95.24 \\
Effects of synthetic chemicals on the environment & Pollution & 14 & 4.76 \\
& Destroys the soil & 184 & 62.58 \\
& Killing of microorganisms & 85 & 28.91 \\
\hline
\end{tabular}

Table 5. Consumers' Purchasing Frequency and Expenditure

\begin{tabular}{lcccc}
\hline Variable & Mean purchase per week & Standard Deviation & Mean expenditure (GH)) per week & Standard Deviation \\
\hline Fruits & & & & \\
Water Melon & 1.74 & 1.36 & 4.23 & 3.40 \\
Mango & 1.85 & 1.71 & 2.68 & 2.36 \\
Pawpaw & 1.37 & 1.30 & 2.21 & 2.22 \\
Pineapple & 1.68 & 1.40 & 3.18 & 2.95 \\
Orange & 2.68 & 2.07 & 2.28 & 2.15 \\
\hline Average & 1.86 & 1.57 & 2.92 & 2.62 \\
\hline Vegetables & & & 2.99 & 4.11 \\
Green Pepper & 1.77 & 2.26 & 2.60 & 1.82 \\
Carrot & 1.65 & 1.47 & 2.47 & 2.12 \\
Cabbage & 1.25 & 1.09 & 5.10 & 3.71 \\
Tomato & 3.68 & 2.89 & 3.34 & 2.34 \\
Garden Eggs & 3.35 & 3.14 & 3.30 & 2.82 \\
\hline Average & 2.34 & 2.17 & \\
\hline
\end{tabular}


Table 6. Respondents' responses on WTP for organic products

\begin{tabular}{|c|c|c|c|}
\hline Selected Products & WTP up to $50 \%$ premium & WTP 51 to $100 \%$ premium & WTP above $100 \%$ premium \\
\hline \multicolumn{4}{|l|}{ Fruits } \\
\hline Water Melon & 267 (83.96\%) & 189 (59.43\%) & 48 (15.09\%) \\
\hline Mango & $234(73.58 \%)$ & 158 (49.69\%) & $44(13.84 \%)$ \\
\hline Pawpaw & $240(75.47 \%)$ & 154 (48.43\%) & $36(11.32 \%)$ \\
\hline Pineapple & 222 (69.81\%) & $152(47.80 \%)$ & 27 (8.49\%) \\
\hline Orange & $267(83.96 \%)$ & 177 (55.66\%) & $54(16.98 \%)$ \\
\hline \multicolumn{4}{|l|}{ Vegetables } \\
\hline Green Pepper & 255 (80.19\%) & 167 (52.52\%) & 38 (11.95\%) \\
\hline Carrot & 261 (82.08\%) & 174 (54.52\%) & 45 (14.15\%) \\
\hline Cabbage & 246 (77.36\%) & 168 (52.83\%) & 38 (11.95\%) \\
\hline Tomato & $264(83.02 \%)$ & $183(57.55 \%)$ & $56(17.61 \%)$ \\
\hline Garden Eggs & 255 (80.19\%) & 154 (48.43\%) & 27 (8.49\%) \\
\hline
\end{tabular}

WTP: Willingness to pay

Table 7. Variables used in the regression analysis

\begin{tabular}{|c|c|c|c|}
\hline Variable & Definition of variable & Mean & Standard Deviation \\
\hline \multicolumn{4}{|c|}{ Dependent Variables } \\
\hline WTPFRUIT & Willingness to pay higher premium price for organic fruit & & \\
\hline WTPVEG & Willingness to pay higher premium price for organic vegetable & & \\
\hline \multicolumn{4}{|c|}{ Independent Variables } \\
\hline \multicolumn{4}{|c|}{ Socio-Demographic Characteristics } \\
\hline GENDER & Gender of Respondents & 0.311 & 0.46 \\
\hline AGE 2 & Respondents from 30 to 50 years & 0.55 & 0.40 \\
\hline AGE 3 & Respondents above 50 years & 0.09 & 0.29 \\
\hline EDU & Number of years of formal education & 9.00 & 4.37 \\
\hline MARISTAT & Marital status of respondents & 0.68 & 0.47 \\
\hline EMPMNT & Employment status of respondents & 0.80 & 0.40 \\
\hline HHSIZE & Household size of respondents & 4.26 & 2.27 \\
\hline INCOMELOW & Average income below GH $\$ 500$ & 0.29 & 0.46 \\
\hline INCOMEMIDD & Average income from $\mathrm{GH} \$ 500$ to $\mathrm{GH} \$ 1000$ & 0.40 & 0.49 \\
\hline INCOMEHIGH & Average income aboveGH $\$ 1000$ & 0.31 & 0.46 \\
\hline \multicolumn{4}{|c|}{ Awareness Variables } \\
\hline AWARE & Awareness of organic foods & 0.75 & 0.44 \\
\hline KNOW & Knowledge of chemical residues in chemically grown fruits and vegetables & 0.77 & 0.42 \\
\hline PESTCONCERN & Concern about pesticides residues in chemically grown fruits and vegetables & 0.84 & 0.37 \\
\hline HRISK & $\begin{array}{l}\text { Knowledge about health risk associated the consumption of chemically grown fruits and } \\
\text { vegetables }\end{array}$ & 0.84 & 0.37 \\
\hline ECONCERN & Concern that chemicals used in conventional farming affect the environment & 0.95 & 0.21 \\
\hline
\end{tabular}

\subsection{Respondents' Responses on Consumers' WTP}

The distribution of responses on consumers' WTP was assessed to provide a fair idea on the number of respondents and percentage premium they were willing to pay for organic fruits and vegetables. About 69.81 to $83.96 \%$ of respondents indicated that they were willing to pay up to $50 \%$ premium, $47.80 \%$ to $59.43 \%$ indicated that they were willing to pay $51 \%$ to $100 \%$ premium while $8.49 \%$ to $16.98 \%$ indicated that they were WTP more than $100 \%$ premium for organic fruits over the prices of the conventional fruits on the markets. This trend is corroborating to finding in North America [32] which indicated that majority of respondents were willing to pay between 15 and 69 cents above the 50 cents purchase price of grapefruit for a lower pesticide residue and 5\% of the respondents indicated that they would pay more than double the price for a safer grapefruit as compared to a regular fresh grapefruit. The logit regression analysis was performed with the consumers' characteristics to determine the significant characteristics that influence consumers' willingness to pay for organic fruits and vegetables. The descriptive statistics of the variables used in the logit regression analysis are presented in Table 7.

\subsection{Consumption of Organic Fruits}

The empirical findings on WTP for organic fruits are shown in Table 8. The coefficients of AGE1 were negative and statistically significant at $1 \%$ in the WTP model for all the organic fruits. These estimated coefficients suggest that older consumers $(\geq 30 \mathrm{yrs})$ were likely to pay a premium for the organic fruits than younger ones (<30yrs). These empirical findings agree with other studies [36,37] which indicated a negative relationship between younger consumers and WTP for organic products. However, these findings contradict with the 
studies by Smith et al. [38] for US consumers and Akgungor et al. [39] for Turkish consumers.

The coefficients for education (EDU) variable were negative and statistically significant at $1 \%$ in the WTP model for all the organic fruits. These empirical findings indicate that consumers who have higher educational levels were less likely to pay more for organic fruits. These findings agree with the studies by Govindasamy and Italia [40] for US consumers and Boccaletti and Nardella [41] for Italian consumers which showed a negative correlation between education and WTP for organic fruits. However, the findings are contrary to studies conducted by Du Toit et al. [42] for consumers in South Africa and Akgungor et al. [39] for Turkish consumers which showed a positive correlation between education and WTP for organic fruits.

The coefficient of the average household income (INCOME) variable was positive and significant at 10\% for pineapple. This suggests that consumers with high income levels were more likely to pay a premium for organic pineapple. This finding agrees with that of Piyasiri et al. [43] for Sri Lankan consumers, and Arbindra and Wanki [44] for US consumers.
The coefficients of the marital status (MARISTAT) variable were positive and significant at $5 \%$ for water melon, mango and pawpaw. This indicates that respondents who were married were more likely to pay more for water melon, mango and pawpaw. The coefficients of the employment status (EMPMNT) variable were negative and significant for mango, pawpaw and orange. This indicates that consumers who were employed were less likely pay more for organic fruits.

The awareness variables like AWARE, KNOW, PESTCONCERN, HRISK and ECONCERN which were investigated in the WTP models were all statistically significant $(p<0.05)$. The variable AWARE representing the degree of awareness of organic foods carried a negative coefficient for WTP for mango and significant at $10 \%$. The results indicate that the consumers who were aware of organic food were less likely to pay more for organic mango. It may be that these consumers may not believe there is a difference in quality between organic and conventional produce. This finding is contrary to the study by Govindasamy et al. [45] for US consumers who found a positive correlation between awareness and willingness to pay a premium.

Table 8. Logit estimates on consumers' WTP for organic fruits

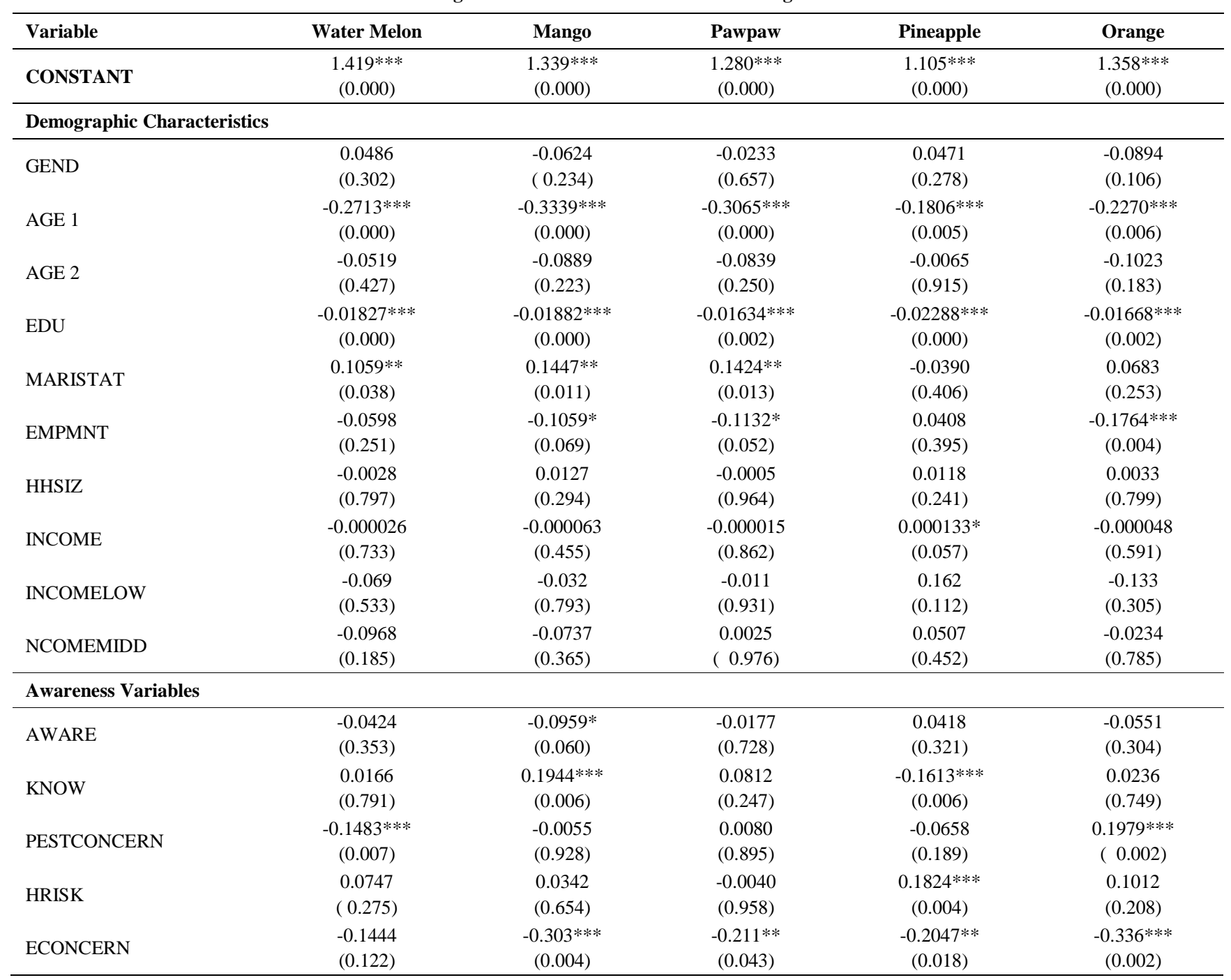

Note: $* * *$ indicates significant at $p<0.01$

$* *$ indicates significant at $p<0.05$

* indicates significant at $p<0.10$

Values in parentheses are $p$ - values. 
The coefficient of PESTCONCERN was positive and significant at $1 \%$ for orange. This empirical finding confirm the hypothesis that the probability to pay higher price premium for organic fruits increases with increased consumer concerns for the use of inorganic pesticides in fruits production, thus confirming what Misra et al. [36] found for US fruits consumers. Health risk concerns associated with consumption of chemically produced fruits was positively associated with the WTP for pineapples. The positive sign of the HRISK indicates that the consumers with health risk concern were more likely to be willing to pay a premium for organic fruits.

The coefficients of the environmental concern (ECONCERN) variable were negative and significant at for mango, pawpaw, orange and pineapple. This indicates that the consumers with environmental concerns were less likely to pay more for organic mango, pawpaw, orange and pineapple. Knowledge of chemical residues (KNOW) associated with consumption of chemically produced fruits was positively correlated to the WTP for organic mangoes. The positive sign indicates that the consumers with knowledge of chemical residues in conventional fruits were more likely to be willing to pay a premium for the organic type.

\subsection{Consumption of Organic Vegetables}

The empirical results on WTP for organic vegetables are shown in Table 9. The coefficients of AGE1 were positive and statistically significant at $1 \%$ in the WTP model for carrots, cabbage and garden eggs, and 10\% for tomatoes. These estimated coefficients suggest that young consumers (less than 30 years) as compared to middle aged (from 30 to 50 years) and older consumers (older than 50) were more WTP for organic carrots, cabbage, garden eggs and tomatoes. These findings are in agreement with Smith et al. [38] for US consumers but in contrast with a study [36] which indicated a negative relationship between younger consumers and WTP for organic products.

The coefficients of education (EDU) variable were negative and statistically significant at $1 \%$ in the WTP model for all the organic vegetables. These empirical findings indicate that consumers who have higher educational levels were less likely to pay more for organic vegetables. These findings are contrary to Piyasiri et al. [43] who concluded that highly educated consumers are more willing to pay a premium for organically produced vegetables.

Table 9. Logit estimates on consumers' WTP for organic Vegetables

\begin{tabular}{|c|c|c|c|c|c|}
\hline Variable & Green Pepper & Carrot & Cabbage & Tomato & Garden Eggs \\
\hline CONSTANT & $\begin{array}{c}1.191^{* * * *} \\
(0.000)\end{array}$ & $\begin{array}{c}1.184^{* * *} \\
(0.000)\end{array}$ & $\begin{array}{c}0.985 * * * \\
(0.000)\end{array}$ & $\begin{array}{c}0.795 * * * \\
(0.000)\end{array}$ & $\begin{array}{c}0.882 * * * \\
(0.000)\end{array}$ \\
\hline \multicolumn{6}{|c|}{ Demographic Characteristics } \\
\hline GEND & $\begin{array}{l}-0.0145 \\
(0.766)\end{array}$ & $\begin{array}{l}-0.0101 \\
(0.844)\end{array}$ & $\begin{array}{l}0.0408 \\
(0.404)\end{array}$ & $\begin{array}{c}-0.0836 * \\
(0.063)\end{array}$ & $\begin{array}{l}0.0190 \\
(0.703)\end{array}$ \\
\hline AGE 1 & $\begin{array}{l}0.0976 \\
(0.177)\end{array}$ & $\begin{array}{c}0.2053^{* * *} \\
(0.007)\end{array}$ & $\begin{array}{c}0.2360 * * * \\
(0.001)\end{array}$ & $\begin{array}{c}0.1118 * \\
(0.092)\end{array}$ & $\begin{array}{c}0.1983 * * * \\
(0.007)\end{array}$ \\
\hline AGE 2 & $\begin{array}{l}0.0705 \\
(0.298)\end{array}$ & $\begin{array}{l}0.0516 \\
(0.469)\end{array}$ & $\begin{array}{l}0.0254 \\
(0.708)\end{array}$ & $\begin{array}{l}0.0681 \\
(0.274)\end{array}$ & $\begin{array}{l}0.0826 \\
(0.233)\end{array}$ \\
\hline EDU & $\begin{array}{c}-0.01578 * * * \\
(0.001)\end{array}$ & $\begin{array}{c}-0.01841^{* * *} \\
(0.000)\end{array}$ & $\begin{array}{c}-0.01706^{* * *} \\
(0.000)\end{array}$ & $\begin{array}{c}-0.01650 * * * \\
(0.000)\end{array}$ & $\begin{array}{c}-0.01515^{* * *} \\
(0.002)\end{array}$ \\
\hline MARISTAT & $\begin{array}{l}0.0247 \\
(0.640)\end{array}$ & $\begin{array}{l}-0.0167 \\
(0.763)\end{array}$ & $\begin{array}{l}0.0014 \\
(0.978)\end{array}$ & $\begin{array}{l}0.0780 \\
(0.109)\end{array}$ & $\begin{array}{l}0.0457 \\
(0.397)\end{array}$ \\
\hline EMPMNT & $\begin{array}{c}-0.1890 * * * \\
(0.001)\end{array}$ & $\begin{array}{c}-0.0048 \\
(0.933)\end{array}$ & $\begin{array}{l}-0.0831 \\
(0.125)\end{array}$ & $\begin{array}{l}-0.0420 \\
(0.397)\end{array}$ & $\begin{array}{l}-0.0426 \\
(0.441)\end{array}$ \\
\hline HHSIZE & $\begin{array}{l}-0.0012 \\
(0.916)\end{array}$ & $\begin{array}{l}0.0174 \\
(0.143)\end{array}$ & $\begin{array}{l}0.0155 \\
(0.170)\end{array}$ & $\begin{array}{l}0.0034 \\
(0.744)\end{array}$ & $\begin{array}{l}0.0069 \\
(0.548)\end{array}$ \\
\hline INCOME & $\begin{array}{c}0.000031 \\
(0.695)\end{array}$ & $\begin{array}{c}-0.000134 \\
(0.104)\end{array}$ & $\begin{array}{c}0.000057 \\
(0.468)\end{array}$ & $\begin{array}{c}0.000105 \\
(0.145)\end{array}$ & $\begin{array}{c}0.000002 \\
(0.977)\end{array}$ \\
\hline INCOMELOW & $\begin{array}{l}-0.099 \\
(0.389)\end{array}$ & $\begin{array}{l}-0.172 \\
(0.155)\end{array}$ & $\begin{array}{c}0.042 \\
(0.711)\end{array}$ & $\begin{array}{c}0.173 \\
(0.101)\end{array}$ & $\begin{array}{c}0.066 \\
(0.573)\end{array}$ \\
\hline NCOMEMIDD & $\begin{array}{l}-0.0178 \\
(0.814) \\
\end{array}$ & $\begin{array}{c}-0.2024^{* *} \\
(0.011)\end{array}$ & $\begin{array}{r}-0.0483 \\
(0.524) \\
\end{array}$ & $\begin{array}{l}0.1186 \\
(0.089) \\
\end{array}$ & $\begin{array}{l}0.0792 \\
(0.306)\end{array}$ \\
\hline \multicolumn{6}{|c|}{ Awareness Variables } \\
\hline AWARE & $\begin{array}{l}-0.0776 \\
(0.102)\end{array}$ & $\begin{array}{l}-0.0818 \\
(0.101)\end{array}$ & $\begin{array}{l}-0.0780 \\
(0.100)\end{array}$ & $\begin{array}{l}0.0601 \\
(0.167)\end{array}$ & $\begin{array}{l}-0.0885 \\
(0.068)\end{array}$ \\
\hline KNOW & $\begin{array}{c}0.1280 * \\
(0.050)\end{array}$ & $\begin{array}{l}-0.0298 \\
(0.664)\end{array}$ & $\begin{array}{l}0.0028 \\
(0.966)\end{array}$ & $\begin{array}{l}0.0533 \\
(0.373)\end{array}$ & $\begin{array}{l}0.1020 \\
(0.126)\end{array}$ \\
\hline PESTCONCERN & $\begin{array}{l}-0.0272 \\
(0.630)\end{array}$ & $\begin{array}{l}0.0436 \\
(0.462)\end{array}$ & $\begin{array}{l}-0.0850 \\
(0.132)\end{array}$ & $\begin{array}{l}0.0153 \\
(0.767)\end{array}$ & $\begin{array}{c}-0.1077 * \\
(0.062)\end{array}$ \\
\hline ECONCERN & $\begin{array}{c}-0.2401^{* *} \\
(0.013)\end{array}$ & $\begin{array}{c}-0.220 * * \\
(0.032)\end{array}$ & $\begin{array}{c}-0.1891^{*} \\
(0.051)\end{array}$ & $\begin{array}{c}-0.2914^{* * *} \\
(0.001)\end{array}$ & $\begin{array}{c}-0.3324 * * * \\
(0.001)\end{array}$ \\
\hline
\end{tabular}

Note: $* * *$ indicates significant at $p<0.01$

$* *$ indicates significant at $p<0.05$

$*$ indicates significant at $p<0.10$

Values in parentheses are $p$ - values. 
The awareness variables like, PESTCONCERN, KNOW, HRISK and ECONCERN which were investigated in the WTP models were all statistically significant. The variable KNOW representing the knowledge of chemical residues associated with the consumption of chemically produced vegetables carried a positive coefficient for WTP for green pepper at $10 \%$. The results indicate that consumers who have knowledge of chemical residues associated with the consumption of chemically produced vegetables were more likely to pay more for organic green pepper. This finding agreed with the study by Govindasamy et al. [45] for US consumers.

The coefficient of PESTCONCERN was negative and this empirical finding refute the hypothesis that the probability to pay higher price premium for vegetables increases with increased consumer concerns for the use of inorganic pesticides in vegetable production. This finding is contrary to the studies of Misra et al. [36] for US vegetable consumers, and Boccaletti and Moro [41] for Italian vegetable consumers.

Health risk concerns (HRISK) associated with consumption of chemically produced vegetables was positively associated with the WTP for carrots, cabbage, tomatoes and garden eggs. The positive sign of the HRISK indicates that consumers with health risk concern were more likely to pay more for organic vegetables. These empirical findings agree with Nouhoheflin et al. [35] who found a significant positive relationship between health risk and WTP for organic vegetables.

\subsection{Estimation of Market Potential}

The number of possible buyers is at least the consumers in Techiman, therefore the number of possible buyers will be 67,241 . It was assumed that at any purchase, the consumer buy at least $0.5 \mathrm{~kg}$ of the product. As shown in Table 10, the total market size for organic fruits and vegetables were estimated at about GHథ3,514,383,194.70 and GH\$5,341,348,087.50 respectively. The market potential of $\mathrm{GH} \$ 1,305,901,555.00$ for orange was the highest amongst the organic fruits investigated. Pawpaw on the other hand, had the minimum estimated market size of GH\$255,942,995.50. For the organic vegetables, tomatoes had the largest market potential of GH\$2,462,274,618.00 with cabbage having the minimum estimated market size of GH\$284,093,225.00.

\section{Conclusion}

Most consumers are aware of organic foods in the Techiman market of Ghana and they became aware generally through the radio and school/books. The main factor that influence consumers to purchase organic foods is based on health grounds and they generally preferred buying organic fruits and vegetables directly from farmers or market retailers. The consumers indicated that organic fruits and vegetables should be labelled or sold in designated organic markets or stores.

Most of the consumers acknowledged that they are aware of the environmental and health risks associated with chemically grown fruits and vegetables. The consumers exhibited positive perception on organic fruits and vegetables with regards to benefits, quality, cost and environmental risks as compared to the conventionally produced fruits and vegetables.

The most characteristics consumers would seek when purchasing organic fruits and vegetables were freshness, insect damage free and colour/ripeness while size and hardness would be the least characteristics. The study found that there is a huge market potential for organic fruits and vegetables in the Techiman market.

Almost all the consumers were willing to pay up to $50 \%$ premium for the organic fruits and vegetables. Some of socio-demographic characteristics such as age, marital status and income significantly influenced consumers' willingness to pay a premium for organic fruits and vegetables. Awareness variables such as knowledge of chemical residues in chemically grown fruits and vegetables and its associated health risk significantly influenced consumers' willingness to pay a premium for organic fruits and vegetables.

Table 10. Empirical Estimation of the Market Potential

\begin{tabular}{|c|c|c|c|c|c|}
\hline Product & $\begin{array}{c}\text { Number of } \\
\text { possible buyers }\end{array}$ & $\begin{array}{c}\text { Average premium } \\
\text { WTP(GH4) }\end{array}$ & $\begin{array}{c}\text { Purchasing rate } \\
\text { per year }\end{array}$ & $\begin{array}{l}\text { Purchasing quantity } \\
\text { (Kg) per year }\end{array}$ & $\begin{array}{c}\text { Market potential } \\
\text { (GHC) }\end{array}$ \\
\hline \multicolumn{6}{|l|}{ Fruits } \\
\hline Water Melon & 67,241 & 2.00 & 90.48 & 45.24 & $550,477,214.70$ \\
\hline Mango & 67,241 & 1.50 & 96.20 & 48.10 & $466,708,350.00$ \\
\hline Pawpaw & 67,241 & 1.50 & 71.24 & 35.62 & $255,942,995.50$ \\
\hline Pineapple & 67,241 & 1.50 & 87.36 & 43.68 & $384,875,864.80$ \\
\hline Orange & 67,241 & 2.00 & 139.36 & 69.68 & $1,305,901,555.00$ \\
\hline Total & & & & & $3,514,383,194.70$ \\
\hline \multicolumn{6}{|l|}{ Vegetables } \\
\hline Green Pepper & 67,241 & 2.00 & 92.04 & 46.02 & $569,622,825.30$ \\
\hline Carrot & 67,241 & 2.00 & 85.80 & 42.90 & $495,004,035.20$ \\
\hline Cabbage & 67,241 & 2.00 & 65.00 & 32.50 & $284,093,225.00$ \\
\hline Garden Eggs & 67,241 & 1.50 & 174.20 & 87.10 & $1,530,353,384.00$ \\
\hline Total & & & & & $5,341,348,087.50$ \\
\hline
\end{tabular}

WTP: Willingness to pay. 


\section{References}

[1] Obuobie, E., Keraita, B., Danso, G., Amoah, P., Cofie, O. O., Raschid-Sally, L. \& Drechsel, P. (2006). Irrigated urban vegetable production in Ghana: Characteristics, benefits and risks. IWMI RUAF - IDRC - CPWF, Accra, Ghana: IWMI, 150 24-98.

[2] Gold M. V. (2007). What is organic production? National Agricultural Library. United State Department of Agriculture.

[3] Gilroy, D. K., Jesiolowski, J. \& Sinnott, P. A., (1993). The Basic Book of Organic Gardening. Rodale Press, Inc., Emmaus, Pennsyvania: 241-253.

[4] Phillips, J. C. \& Peterson, H. C. (2001). Demand Overview for Organic Produce. Staff Paper No. 2001 - 06 Department of Agricultural Economics Michigan State University, East Lansing, USA.

[5] Karen, K. \& Greene, C., (2005). Widespread Adoption of Organic Agriculture in the US: Are Market-Driven Policies Enough? Selected Paper prepared for presentation at the American Agricultural Economics Association Annual Meeting, Providence, Rhode Island, July 24-27, 2005.

[6] Thompson, G. D. (1998). Consumer Demand for Organic foods: What we know and What Need to Know. American Journal of Agricultural Economics, 80(5): 1113-1118.

[7] Lohr, L. (1998). Implications of Organic Certification for Market Structure and Trade. American Journal of Agricultural Economics, 80(5): 1125-1129.

[8] Myers, S. \& Rorie, S. (2000). Facts and Stats: The Year in Review. Organic and Natural News: 20-25.

[9] IFOAM (2003). Organic \& Like-Minded Movements in Africa. International Federation of Organic Agriculture Movements (IFOAM), Bonn, 102-108.

[10] IFOAM and FiBL (2006). The World of Organic Agriculture. Statistics and Emerging Trends 2006. International Federation of Organic Agriculture Movements, Bonn and Research Institute of Organic Agriculture FiBL, Frick, Pp 27-35.

[11] Wang, Q. \& Sun, J. (2003). Consumer preference and demand for organic food: Evidence from a Vermont survey. Paper prepared for American Agricultural Economics Association Annual Meeting July: 1-12.

[12] Hine, R. \& Pretty, J., (2007). Promoting Production and Trading Opportunities for Organic Agricultural Products in East Africa Capacity Building Study 3. Organic Agriculture and Food Security in East Africa, 43 -55.

[13] Ghana Statistical Service (GSS), (2013). 2010 Population and Housing Census. .National Analytical Report, May, 2013: 72-112.

[14] Assibey-Mensah, G. O. (1998). Ghana's Women-in-Developmen Program: Problems, Issues, and Prescription. Journal of Black Studies, 29: 277-295.

[15] Ghana Statistical Service, (2008). Ghana Living Standards Survey. Report of the Fourth Round (GLSS 5), September, 2008: 101-124.

[16] Akgungor, S., Abay, C. \& Miran, B. (1997). Marketing of organically grown agricultural products in Turkey: Status and prospects. Agricultural Production and Nutrition: Proceedings of an International Conference, Boston, MA. March 19-21, 1997.

[17] Jolly, D. A., Schutz, G. H., Diaz-Knauf, K. V. \& Johal, J. (1989). Organic foods: Consumer attitudes and use. Food Technology, November: 60-66.

[18] Hutchins, R. K. \& Greenhalgh, L. A., (1997). Organic confusion: Sustaining competitive Advantage. British Food Journal, 99(9): 336-338.

[19] Wang, Q., Halbrendt, C. \& Webb, S. (1997). Consumer Demand for Organic food in China: Evidence from Survey Data. Agricultural Production and Nutrition: Proceedings of an International Conference, Boston, MA. March 19-21, 1997.

[20] Kenanoglu, Z. \& Karahan, O. (2002). Policy implementations for organic agriculture in Turkey. British Food Journal, 104(5): 300-318.

[21] Demeritt, L. (2002). All Things Organic 2002: A Look at the Organic Consumer. The Hartman Group, Bellevue, WA.

[22] Hill, H. \& Lynchehaun, F. (2002). Organic milk: Attitudes and consumption patterns. British Food Journal, 104 (7): 526-542.

[23] Cunningham, R. (2002). Who is the Organic Consumer? A Paper presented at Growing Organic Conference, Red Deer, Alberta, March 11-12, 2002

[24] Fotopoulos, C. \& Krystallis, A. (2002). Purchasing motives and profile of the Greek organic consumer: a countrywide survey. British food journal, 104(9): 730-765.
[25] Magnusson, M. K., Arvola, A, Ulla-Kaisa, K. H, Lars, A. and PerOlow, S. (2001). Attitudes towards organic foods among Swedish consumers. British Food Journal, 103(3): 109-227.

[26] Tregear A., Dent, J. B. \& McGregor, M. J., (1994). The demand for organically-grown produce. British Food Journal, 96(4): 21-25.

[27] Wandel, M. \& Bugge, A., (1997). Environmental concern in consumer evaluation of food quality. Food Quality and Preference, 8(1): $19-26$

[28] Huang, C. L. (1996). Consumer preferences and attitudes towards organically grown produce. European Review of Agricultural Economics, 23(3): 331-342.

[29] Swanson, R. B. \& Lewis, C. E. (1993). Alaskan direct-market consumers: perceptions of organic produce. Home Economics Research Journal, 22: 138-155.

[30] Bourn, D. \& Prescott, J. (2002). A comparison of the nutritional value, sensory qualities and food safety of organically and conventionally produced foods. Critical Reviews in Food Science and Nutrition, 42(1): 1-34.

[31] Wolf, M. M. (2002). An Analysis of the Impact of Price on Consumer Interest in Organic Grapes and a Profile of Organic Purchasers. A paper presented at the American Agricultural Economics Association Annual Meeting, Long Beach, California, July 28-31, 2002.

[32] Buzby, J. C. \& Skees, J. (1994). Consumers want reduced exposure to pesticides in food. Food Review, 17(2): 19-22.

[33] Cranfield, J. A. L. \& Magnusson, E. (2003). Consumers' Willingness to Pay for Pesticides Free Food Products: An Ordered Probit Analysis. International Food and Agribusiness Management Review, 6(4): 13-30.

[34] Boccaletti, S. \& Nardella, M. (2000). "Consumer willingness to pay for pesticide-free fresh fruit and vegetables in Italy". International Food and Agribusiness Management Review, 3: 297310

[35] Nouhoheflin, T., Coulibaly, O., Andy, J., Cherry, Al-Hassan \& Patrice Y. (2004). Consumers' Perception and Willingness to Pay for Organic Vegetable in Benin and Ghana. Shaping the Future of African Agriculture for Development: The Role of Social Scientists. Proceedings of the Inaugural Symposium, 6 to 8 December 2004, Grand Regency Hotel, Nairobi, Kenya.

[36] Misra, S. K., Huang, C. L. \& Ott, S. L. (1991). Consumer Willingness to Pay Pesticide-Free Fresh Produce. Western Journal of Agricultural Economics, 16:218-227.

[37] Loureiro, M. L. \& Hine, S. (2002). Discovering Niche Markets: A Comparison of Consumer Willingness to Pay for Local (Colorado Grown), Organic, and GMO Free Products”. Journal of Agricultural and Applied Economics, 34(3): 477-487.

[38] Smith, T. A., Lin, B - H. and Huang C. L. (2008). Organic Premiums of U.S. Fresh Produce. Proceedings of the NCCC - 134 Conference on Applied Commodity Price Analysis, Forecasting, and Market Risk Management. St. Louis, MO.

[39] Akgungor, S., Bulent, M. \& Abay, C. (2007). Consumer Willingness to Pay for Organic Products in Urban Turkey". Contributed Paper prepared for presentation at the 105th EAAE Seminar, International Marketing and International Trade of Quality Food Products, Bologna, Italy, March 8-10, 2007.

[40] Govindasamy, R. \& Italia, J. (1998). Predicting the Influence of Demographic Characteristics on the Willingness to Pay for Fresh Fruits and Vegetables. Journal of Food Products Marketing, 4(4): 25-38.

[41] Boccaletti, S. \& Moro, D. (2000). Consumer Willingness-To-Pay for GM Food Products in Italy. AgBioForum, 3(4): 259-267.

[42] Du Toit, L. \& Crafford, S. (2003). Beliefs and purchasing practices of Cape Town consumers regarding organically produced food. Journal of Family Ecology and Consumer Sciences, 31: 1-11.

[43] Piyasiri, A. G. S. A. \& Ariyawardana, A. (2002). Market Potentials and Willingness to Pay for Selected Organic Vegetables in Kandy. Sri Lankan Journal of Agricultural Economics, 4(1): 107-119.

[44] Arbindra, R. \& Wanki, M. (2005). Perceived Risks of Agrobiotechnology and Organic Food Purchase in the United States. Selected Paper prepared for presentation at the Southern Agricultural Economics Association Annual Meetings, Little Rock, Arkansas, February 5-9, 2005.

[45] Govindasamy, R., DeCongelio, M. \& Bhuyan, S. (2006). An Evaluation of Consumer Willingness to Pay for Organic Produce in the North-eastern US. Journal of Food Products Marketing, 11(4): $3-20$ 